\title{
OPTIMIZATION OF HUMAN RESOURCES MANAGEMENT IN ISLAMIC BANKING
}

\author{
Fitra Azkiya Firdiansyah \\ Universtitas Islam Negeri (UIN) Sunan Ampel Surabaya, Indonesia \\ ferdiazkiya@gmail.com \\ https://doi.org/10.46367/jps.v2i2.375
}

Received: Aug 03, 2021 Revised: Aug 29, 2021 Accepted: Sep 06, 2021 Published: Oct 14, 2021

\begin{abstract}
So far, the rapid development of Islamic banking has not been supported by competent resources according to Islamic principles. The resources contained in Islamic banking so far have been a shift from conventional banking, resulting in the incompetence of these resources in Islamic banking. This study aims to analyze the optimization of human resource management in Islamic banking following Islamic principles. The method in this research is descriptive analysis with a qualitative approach. The analysis uses deductive and inductive techniques from various published literature. The results of the study show that human resources in Islamic banking are not yet optimal. The development and development of available resources must align with the position, training, and development of attitudes and managerial skills instilled with Islamic financial and ethical principles. Islamic banking must cooperate with universities in the coaching process to absorb potential resources with added value and have Islamicbased competencies.
\end{abstract}

Keywords: Optimization, Human Resource Management, Islamic Banking.

\section{INTRODUCTION}

The banking sector has a strategic role in supporting national development, leading to increased equity in development and results. This achievement is inseparable from the significant expansion of the office network and Islamic banking services, which are supported by, among others, Islamic banking infrastructure, promotion strategies, and public education in the Islamic banking sector, which are pursued through coordination/synergy between Bank Indonesia and actors (Bank Indonesia 2012). In line with the condition of the national banking industry, the slowdown in economic growth has also affected the growth rate of Islamic banking. Islamic banking assets consisting of Islamic commercial banks, Islamic business units and Islamic rural banks were recorded at IDR 248.1 trillion in 2013 or grew 24.2\% (YoY), lower than the previous year's growth (34.0\%, YoY). Despite the slowdown, the growth of Islamic banking assets was higher than the growth of banking assets nationally, the share of Islamic banking as a whole by including Islamic people's credit bank to the national banking industry increased by $4.61 \%$ to $4.93 \%$ (Melis 2019 ). 
The advancement of human civilization is the fruit of human creativity and innovation. The decline in the quality of the environment is also caused by human carelessness and greed (Firdiansyah, Rosidi, and Nur Iman 2021). In a narrower scope, for example, in a company, human or human resource factors remain the key to the company's progress. A banking industry system that applies digital technology, sufficient capital, the best working methods, well-implemented marketing strategy management, and supported by a potential market will be meaningless if the human aspect does not function properly (Rozalinda 2016). High-tech machines will only operate well if they are run by skilled operators and master the workings of these machines. Abundant capital or funds will only be optimally valuable if managed by a financial manager who is reliable in managing finances. The potential market can only be worked on and controlled by the company if the marketing manager can design marketing programs that touch hearts and foster consumer interest; on the other hand, he must manage marketing amid a flood of competing company products. For a while, some of the things above have shown how the human resource factor is crucial to be appropriately managed in every organization, including business organizations/companies.

Human resources have an important role in the development of the Islamic banking business. Until now, the assets of the Islamic banking industry still have a market share of below 4\% compared to the entire national banking system. The development of the Islamic banking business is still not proliferating in Indonesia because problems hinder the Islamic banking business. Three significant problems hinder business development in Islamic banking (Ramadani 2019). The first problem is the lack of product availability and standardization of Islamic banking products. Second, the lack of understanding (awareness) of Islamic bank products and terms in Islamic banking. The third problem is human resources. The problem is that it is difficult for banks to find competent and qualified Islamic banking human resources. They take a lot of Islamic banking human resources from conventional banking and potential human resources. Very few human resources are taken from Islamic college graduates; this is the anxiety of players in Indonesia's Islamic banking financial institution industry.

Cooperation between the world of education and the banking industry still lacks because Link And Match have not yet fully occurred. In addition, investment in education and development recruitment to provide ready-to-use bankers is still quite expensive. The problem of human resources in Islamic banking is a problem that needs to be resolved together. The problem of Human Resources in Islamic banking is that there is no cooperation between academics and practitioners in producing Human Resources. In fact, with this, we can produce quality human resources for the needs of the Islamic banking industry in Indonesia. The absence of a link and match between education and Islamic banking will affect the literature, lecturers or researchers, and practitioners of Islamic economics in Indonesia. Research and development that has been done will be redundant. These problems have caused human resources in Islamic banking to be less competent in Islamic finance principles and business. This study aims to analyze the optimal empowerment of human resources with efficient recruitment, training, and developmental mechanisms following Islamic principles. 


\section{LITERATURE REVIEW}

\section{Human Resource Management}

Human asset the executives is a vital piece of authoritative administration assignments. How well human resources (HR) is overseen will decide the accomplishment of the association later on. Then again, if HR is not overseen appropriately, viability will not be accomplished. Human Resource is quite possibly the most indispensable component for the association. This happens because, first, HR significantly influences the productivity and adequacy of the association; HR plans and delivers labor and products, screens quality, markets items, dispenses monetary assets, and decides every authoritative objective and methodologies. Second, HR is the association's actual cost in maintaining a business. Due to the significance of HR the board, in case it is overlooked, the association will not prevail with regards to accomplishing its objectives and destinations (Hidayati 2015).

One of the significant issues that need consideration is the nature of HR. The job of HR is highly vital as the agent of organization capacities, precisely arranging, coordinating, authority, and management just as carrying out organization tasks, like promoting, creation, exchange, industry, money, and administration (Cahyani 2017). All administrators should be associated with the HR cycle in an incorporated way. In accomplish the arranged objectives during the time spent getting sorted out, chiefs designate hierarchical assets as per the plans that have been made dependent on an authoritative construction, relegate specialists and obligations, enlist and select, direct preparing and advancement, and spot HR in the correct positions. These are getting sorted out exercises bring forth HR management (Istikhomah, Ngadiman, and Sohidin 2014).

HR the executives is the way toward drawing in, creating, and keeping a labor force. HR the executives is an interaction and work to enlist, create, propel, and assess the general HR required by the organization in accomplishing its objectives. Subsequently, the exercises in HR the executives start from choosing any individual who has the capabilities and has the right to possess a situation in the organization (the right man on the opportune spot) to prepare and foster representatives. HR the executives is a constant interaction that follows the organization's functional cycles, so thoughtfulness regarding HR possesses an exceptional spot in the organization's association. Along these lines, in HR, the board, workers are the principal resources of the organization that should be kept up with appropriately, so the factor of worry in HR, the executives, is simply the human (Jusmaliani 2011).

\section{Individual Competence and Management}

Competence is a complex set of productive elements such as expertise and skills in the organization that distinguishes it from competitors are all capabilities possessed by humans (Sumardjo and Priansa 2018). There are three indicators of individual competence based on Islamic values consisting of: (1) Islamic character in the form of moral ethics, responsibility, emotional intelligence, spiritual, intellectual, and commitment; (2) knowledge of banking is manifested in operational aspects and knowledge of Islamic banking; and (3) Skills in analytical, communication, and managerial skills (Rahmawati 2020). 
Individual competencies should be in line with management competencies. According to Slocum, Hellriegel, and Jackson (2008), competency management (Competency based on management) is a management approach by integrating management principles into human resource management activities that are faced with a series of agreed competencies such as job design, recruitment, selection, performance appraisal, compensation, analysis of training, development, succession planning, rotation, demotion, and promotion according to the agreed competencies which of course support the vision, mission and values of the organization. So, in Islamic banking, management competence is adjusted to individual competence based on Islamic business values (Sari, Muhtadi, and Mansur 2020).

\section{Celestial Management Theory as the Basis for Islamic Business Values}

Celestial management theory is a heavenly theory whose source is from the creator who asserts that all management activities, be it business or state, must be based on spiritual values. These values give a much better meaning than just worldly values. The concept of celestial management consists of three major parts, namely worship (as a place of worship), warfare (war/struggle), and wealth (welfare) (Harahap 2016).

The first main factor, worship (worship), is the first value that becomes a reference in doing business. This value is reduced to ZFCR (zero-based, faith, consistent, and result oriented). Zero-based understanding is that an employee who works must have clarity in viewing his work, resulting in the success of the task being carried out. Faith means that every individual in the organization has a sure faith in God's promise/strong monotheism. Consistent, explaining that workers in the organization to always istiqamah in achieving organizational targets and result oriented, indicating that in the organization, every human being or employee must prioritize achieving targets in the business (Harahap 2016).

The next factor is wealth, which is the second value in business as a prosperous environment and as a place of fair distribution both materially and non-materially. The division of work types must be fair following the description and expertise of each employee. Welfare values contain power, information, knowledge, and reward values (PIKR). Understanding power (strength), is that undivided power will be easily exploited by one party. For this reason, it is necessary to share power (teamwork) to facilitate work between employees. Regarding Information, explaining that the business environment must be transparent, all workers can access it in the business environment. Knowledge obtained by superiors or leaders in a good part of the work that comes from training and development programs should be redistributed to subordinates and vice versa. The last is an understanding of reward, in the form of compensation received by workers in the company must be divided fairly according to the results of their work (Latifah and Ritonga 2020).

The last factor, which is the third value in the concept of sky management, is warfare. The understanding of war or struggle in this theory is related to the scope of business as a place of war/struggle for each individual in upholding a system of justice and welfare for all people. There are four attributes in warfare's value, including MICR (militant, intellectual, competitive and regenerative). The first attribute is militant, meaning that every worker in the business environment 
must have a high spirit as a fighter who is willing to fight for what he believes in solely to gain the pleasure of Allah. Furthermore, intellectuals, workers in companies or organizations must be able to use their minds (intellect), think ahead or go forward and positively advance themselves and the institution where they work. Next is the competitive attribute, which can be interpreted as the ability of workers to compete in a healthy, competent manner and can advance the business to gain a competitive advantage. and the last attribute of warfare is Regenerative, which is a continuous process in maintaining and passing on the values of zikr, power, information, knowledge, and reward values (PIKR), militant, intellectual, and competitive to the next generation in order to achieve competitive advantage and under Islamic law (Harahap 2016).

\section{Problems with Islamic Financial Institutions}

The success of Islamic banks in collecting public funds is closely related to the ability of Islamic banks to reach the location of their customers. The more branch offices, the greater the number of people who save funds or do financing in Islamic banks. The potential and prospects of Islamic banking seem very good to be developed in Indonesia. Several things at least mark this good prospect. First, the majority of the Muslim population in Indonesia is a potential market for the development of Islamic banks. Second, the development of higher education institutions that provide education in Islamic economics and finance is increasingly rapid. Third, there is a fatwa from the Indonesian Ulema Council (IUC) regarding the prohibition of bank interest. Fourth, the government to support the development of Islamic banks is quite positive with the issuance of several regulations and laws regarding Islamic banking (Nafisah 2020). The growth of Islamic financial institutions in the country, which is quite encouraging, is not without facing various problems. Lack of socialization and poor understanding of the community about the products and services of Islamic financial institutions, there is a stigma that says that sharia is only for Muslims, the limited number of workers or competent human resources, and a myriad of other problems.

\section{Riba and Islamic Financial Institutions}

Islam is comprehensive teaching. Islam regulates things that are worship and matters relating to the relationship between humans and other creatures. The goal is that human duties as servants of Allah and caliphs can be carried out perfectly. One aspect that arises in human relations is the economic aspect. Islam provides clear rules in terms of the economy, one of which is the prohibition of usury. Riba is etymologically synonymous with Ziyadah, which means additional. Riba, if interpreted linguistically, means to grow and enlarge. Meanwhile, according to technical terms, usury is an additional taking from primary assets (capital) in vanity (Rozalinda 2016).

Islam strictly prohibits the practice of usury in accordance with the following verse of the Qur'an in Surah Al-Baqarah verse 275:

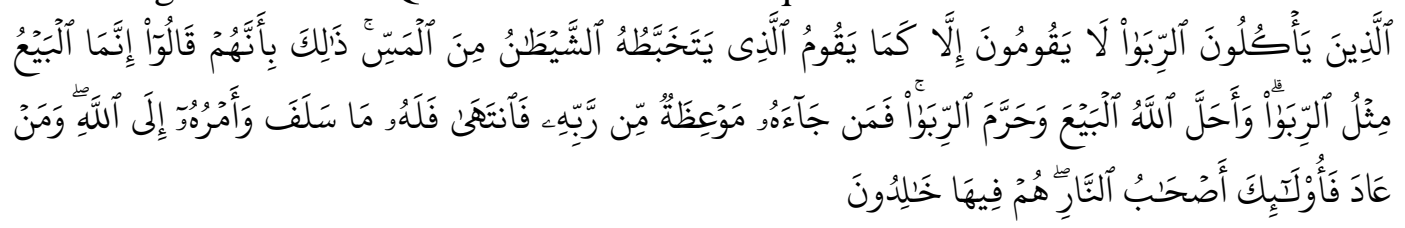


Meaning: "People who eat (transact with) usury cannot stand up, except like a person who staggers because of the devil's trance. This happens because they say that buying and selling are the same as usury. Allah has permitted buying and selling and forbids usury. Whoever has come to him a warning from his Lord (regarding usury), then he stops so that what he has obtained before becomes his and his affairs (up to) to Allah. Whoever repeats (usury transactions), are the inhabitants of hell. They stay in it".

\section{The Role of Human Resources in Organizations and Its Relation to Marketing Activities.}

As we know, the resources owned by organizations are often known as $6 \mathrm{M}$, namely Man (labor or employees), Money (funds or capital), Materials (raw materials), Methods (how to work or technology), Machine (equipment and machines), and Market (market). Of the six resources, the element of labor or employees is the most important. The reason is that all of these elements except the element of labor or employees are inanimate objects that cannot do anything unless they are moved and regulated by humans (Aulia 2011).

The banking business is a service business that is highly dependent on customer trust in transacting with the bank. Customers' trust in Islamic banks and financial institutions will grow based on their experience with these institutions. If he gets timely service, services that are genuinely Islamic-compliant, transparent and honest bookkeeping, sincere and friendly greetings from employees, appropriate benefits, guaranteed security, and comfort, the customer will certainly feel satisfied (Wikaningrum 2011).

Organizational human resource management function (Islamic perspective) (Hardana 2015): (1) Planning (HR arranging) is arranging the labor force successfully and productively to suit the organization's requirements in accomplishing organizational objectives. Arranging is finished by setting up a staffing program. The staffing program incorporates coordinating, coordinating, controlling, getting, creating, redressing, coordinating, keeping up with, restraining, and firing representatives. A decent staffing project will assist with accomplishing the objectives of the organization, representatives, and society. (2) Organizing is an action to put together all representatives by deciding the division of work, work relations, the appointment of power, incorporation, and coordination in the authoritative outline. The association is just a necessary chore. Via doing a decent association will help the acknowledgment of objectives viably. (3) Directing is the movement of coordinating all representatives to cooperate and work viably and proficiently in assisting with accomplishing the objectives of the organization, workers, and society. The pioneer completes bearing by allotting subordinates to perform every one of their responsibilities appropriately. Islam shows a pioneer should ensure his subordinates and pay attention to their yearnings in deciding. (4) Controlling is the movement of controlling all representatives to agree with organization guidelines and work as per plan. In case there are deviations or mistakes, remedial activities and plan enhancements are made. Worker control incorporates participation, discipline, conduct, collaboration, execution of work, and keeping up with the circumstance of the workplace. 


\section{METHODS}

Regarding the research method used in this study is descriptive analysis. The descriptive method is a research method that seeks to obtain information about the description of the situation at the time of the study, then analyzed and tried to explain based on the facts or reality in the field. This study uses a qualitative approach, meaning that research is based on a natural setting as a direct source of data, and the researcher is the key instrument. As explained by (Moleong 2011), qualitative research is a research procedure that produces descriptive data in written or spoken words from people and behaviors that can be experienced. The data analysis method in this study uses qualitative data analysis. Data analysis is the process of systematically searching and compiling the data obtained. This study using deductive and inductive methods. Deductive is a thinking process that begins with putting forward general theories and then putting forward specific realities. Inductive is a thinking process that begins with presenting specific facts from the research results, then ends with general conclusions in the form of generalizations.

\section{RESULTS AND DISCUSSION}

\section{Availability of Islamic Banking Human Resources}

The rise of Islamic banks in Indonesia is not matched by adequate human resources (HR), especially the background of Islamic banking disciplines, so its development is slow. Educational and training institutions are still limited so that staff is educated and experienced in Islamic banking, both from the side of the implementing bank and the central bank (bank supervisors and researchers). The problem now is that Islamic banking takes human resources from conventional banking to find potential employees, while investment in education and development recruitment to provide ready-to-use bankers is still quite expensive. This is a problem because conventional and Islamic banking are two different things, both in principle and operationally in financial transactions. Research has proven Fauzan and Tyasari (2012) that religiosity affects one's work ethic.

Human resource development is very much needed because the success of developing Islamic banks at the micro-level is largely determined by the quality of management and the level of knowledge and skills in managing the bank. Its human resources require general knowledge in banking, understand the implementation of Islamic principles in banking practice, and commit to applying them consistently (istiqamah). The understanding and concern of the majority of the people regarding the system and principles of Islamic banking are not correct; even among Muslim scholars and scholars themselves, there is still no agreement to support the existence of Islamic banks. There are still scholars who have no firm opinion on the existence of Islamic banks, so it feels less firm, this is because; first, the lack of comprehensive information that reaches scholars and scholars about the dangers and destructive effects of the interest system, especially when the monetary crisis and the economy are hit by sluggishness; second, the in-depth and comprehensive understanding of Islamic bank operations; third, intellectual laziness and laziness that tend to be pragmatic so 
that there is an assumption that the current interest system has been running or does not conflict with Islamic provisions.

\section{Correlation of Educational Institutions in the Development of Islamic Banking}

The obstacle to the development of Islamic banks is the existence of human resources, efforts to create reliable and professional human resources in the field of Islamic banking, of course, cannot be separated from the role of educational institutions, which in this case do play a role in producing human resources. Considering the prospect of Islamic banks in the banking world is promising and very good and even received positive responses from all parties, on the contrary, the development of Islamic banks is still in the growth phase; it is very critical/risky. There is only one option, namely how to achieve success, with the support of qualified, integrity, and human moral resources. Considering that there is still a lack of reliable and quality educational institutions/institutions in creating Islamic banking human resources, it's time for all Muslim elements to participate in thinking about its development by preparing reliable and professional human resources through their educational institutions. This solution will undoubtedly answer the shortcomings of Islamic banking academics who have been based on instruments and are more familiar with conventional literature in this way; of course, Islamic banks will gain scientific legitimacy in the community.

\section{Islamic Bank Human Resources Development}

At the beginning of its establishment, each organization designs a vision, mission, and cultural values, which are referred to as central policies or corporate policies. This policy was later revealed to be a strategic policy and an operational policy. No matter how good corporate policies are, if operational policies and strategic policies do not support them, they can fail in achieving business goals. Likewise, in Islamic banking, the corporate policy will advance if there are quality human resources.

Competence development, quality of human resources based on Islamic principles involves individual aspects of knowledge, characteristics (motive, training, and values), and skills embedded in Islamic values. Figure 1 is an example of a core training program aimed at all new employees to improve core competencies related to the vision, mission, and corporate cultural values. In this program, Islamic business values should be instilled by the $3 \mathrm{~W}$ (Worship, Wealth, and Warfare). Functional training is by employee positions; technical competence is also applied following Islamic values and attitude and managerial development programs for employees to be able to instill spiritual aspects.

\section{Human Resource Development}

To optimize human resources in Islamic banking, it is urgent; it is necessary to develop human resources that can be done in various ways, including the following: (1) Formal education. (2) Work environment, in the form of systematic or formal training by the company that employs it. Educational programs for adults and participation in various social, political, cultural, and religious organizations. (3) Self-development on your own. Have an effort to gain 
knowledge, skills, and greater capacity through reading courses or learning from others. Alternatively, more simply, human resources can be developed through education, improving food nutrition, reducing birth rates, and general economic development.

\section{Figure 1. Human Resource Development in Islamic Banks}

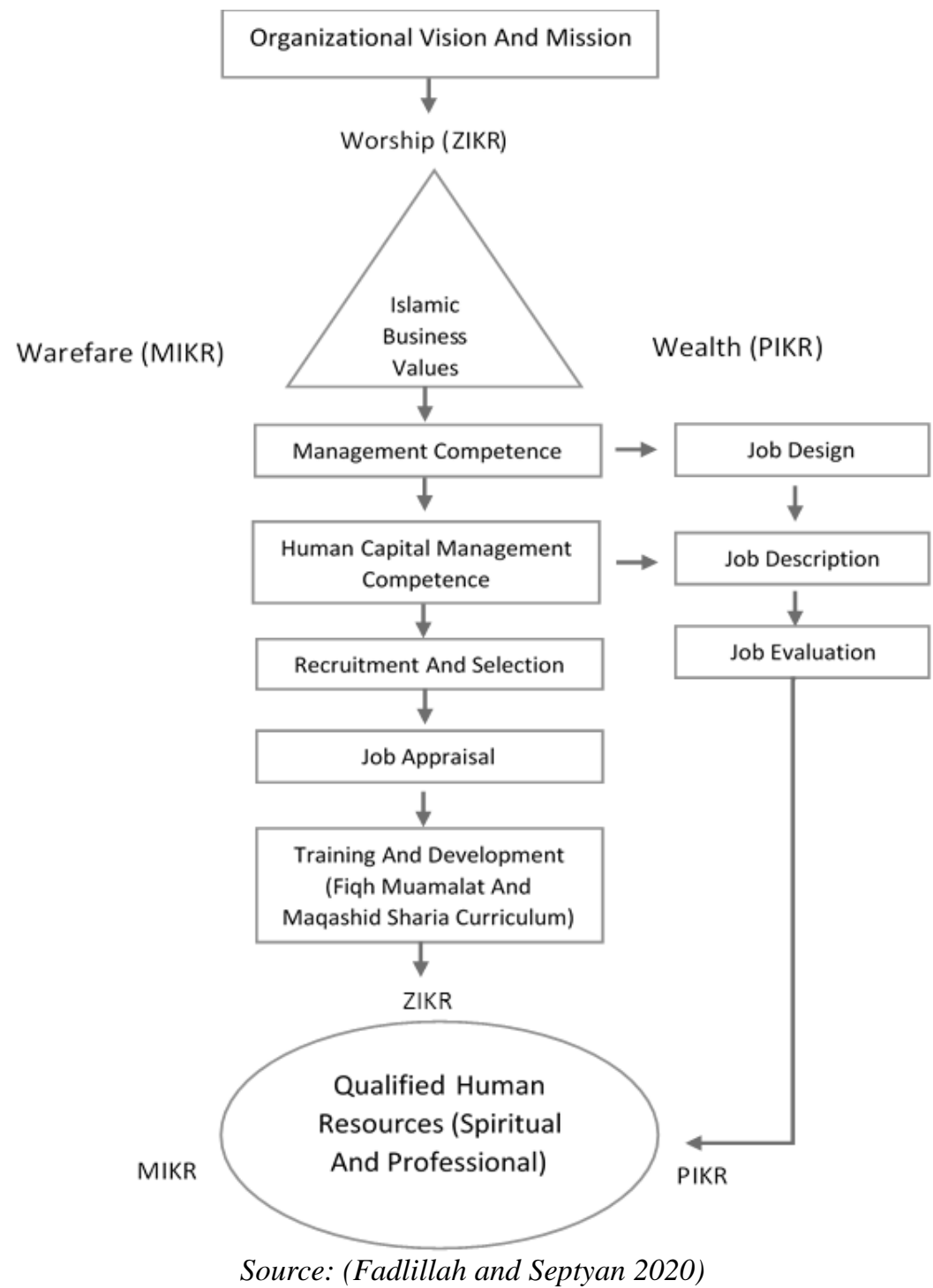

Human resources are a central point that must get serious attention in the context of organization and management because the success of an organization and or the success of a job is largely determined by the participation of the person or human who does it. The principles of human resource empowerment can be formulated in several points, as follows: (1) The principle of competence is the main principle in Islamic management. Competence is the ability or expertise possessed by a person as part of an organization or part of a work process, which is needed to achieve goals. Competence in question can be in the form of cognitive competence, namely the ability of knowledge and analytical power, competence of attitudes such as courage, honesty, dedication or loyalty, 
discipline, and so on, as well as competency skills that include skill, accuracy, and speed in doing a job. (2) The principle of optimization and excellence incompetence The second principle of Islamic management is that the competence possessed must be optimal and exceed another person's competence. The step that a manager must take in determining the human resources to be empowered in a working mechanism is that when a manager is faced with the presence of two or more members of the organization, then a manager must prioritize someone who has competence that exceeds the competence possessed other personally. (3) The principle of the suitability of competence with needs an excellent human resource management system is a system that emphasizes the suitability of the workforce with needs. So in this perspective, an absolute needs analysis is carried out by an organization or individual in the workforce recruitment system. Competence of the workforce that does not meet the needs will only cause chaos, threaten organizational performance, threaten the achievement of goals, and even threaten the sustainability of the organization's existence. (4) The principle of conformity of personal competence with placement The division of work must be adjusted to the ability and expertise so that the implementation of work runs effectively. Therefore, in placing a person to carry out specific tasks, he must use the principle of the right man in the right place. The division of labor must be rational/objective, not subjective emotional-based based on likes and dislikes. (5) The principle of authority and responsibility A person who is given the task or mandate to carry out an action or work must be given the authority and responsibility in carrying out his duties. The granting of this authority is absolute in a management system to ensure the smooth implementation of tasks or work assigned to someone. Without authority, a person will experience doubts in carrying out his duties, which he cannot carry out his duties properly. The authority in a management system must be given in full within the boundaries of its working area without anyone being allowed to intervene because outside intervention will disrupt the working mechanism and lead to not achieving the desired work results or goals. (6) The principle of limiting authority Every authority in Islamic management has its limits. Every individual must own awareness of the limits of this authority in an organizational system. A leader has limits of authority over the people he leads, and employees have limits on authority over their positions and duties. This limitation of authority may not be overstepped or violated. Violation of the limits of authority will damage the organizational system, which ultimately leads to failure and even destruction. (7) The principle of rewards and compensation Reward and Wage systems for employees must receive serious attention to support overall organizational performance. Wages and rewards are compensation that determines the realization of smooth work. Employees who are overwhelmed with feelings of anxiety and lack will find it difficult to concentrate on their duties and obligations, which can result in imperfections at work. Therefore, in the principle of remuneration, it is necessary to think about how employees can work calmly. The payroll system must be taken into account to create discipline and enthusiasm for work to compete to make more significant achievements. The principle of more pay for more prestige (more pay for more achievements) and the principle of equal pay for the same performance need to be applied because if there are differences, it will cause sluggishness in work and may lead to undisciplined actions. 


\section{Link, Match with Universities and Human Resource Providers}

Islamic banking can cooperate with universities or educational institutions providing workers to find potential human resources following Islamic finance principles. This is also a way to accommodate Islamic finance graduates, not switching to conventional finance. So that in the end, Islamic banking and universities both benefit from the absorption of university graduates and Islamic banking parties who have potential Islamic finance human resources.

Education and training programs are strategic programs to increase organizational commitment. Education and education programs will make a significant contribution to the organization if they can match the values of the organization and the values of individuals. To ensure that employees have competencies that are in line with business demands provides training that touches all lines of the organization. The program is reflected in a structured training program according to competency profiles and business fields covering: (1) Advanced program, this can be done to university graduates who have had an internship opportunity in related Islamic banking, so that Islamic banking only needs to provide a little training because the individual is familiar with Islamic banking. This program can be applied every semester to be able to absorb potential human resources. (2) Orientation and development program, as a degree of training to help worker vocation ways, comprises banking staff program, officer development program, management development program, and middle management development program. (3) Banking academy, the financial foundation program, plans to work on the information, abilities, and conduct of representatives, which is helped out in an organized way through a progression of modified exercises. (4) Enhancement program, this is means to keep the information, abilities, and conduct of representatives exceptional as per the requests of the bank's business, industry elements, and worldwide accepted procedures as studios, public preparing, accreditation projects, and graduate degree grant programs.

The bank fully manages all training, education, and leadership development with sources both internal and external. With the costs incurred, it has succeeded in increasing the learning culture of employees both through inclass coaching and mentoring, self-learning through an interactive learning process in e-learning. Learning through e-Learning continues to be developed to improve employee competence. Every employee can now access various training modules through e-Learning. Module reading activities and online tests are also part of the pre-class training integrated with in-classroom training.

\section{Human Resource Management in Islamic Banking}

The development of Islamic banks and financial institutions needs to be accompanied by the provision of competent, reliable, and professional human resources in Islamic economics and business. The public is looking forward to the reassuring and profitable services of Islamic banks and financial institutions. One of the keys is in the aspect of human resources/employees owned by the company. The paradigm of human resource management in Islamic banks and financial institutions needs to be refined and reorganized to create an ideal Islamic financial institution. Recruitment of employees of Islamic banks and financial institutions must prioritize competence, be free from fraud, and be well planned. The 
employee development process must be carried out on an ongoing basis and show the Islamic distinction.

Compensation must be given in a fair, appropriate, and timely manner to improve employee morale. Fostering morale and motivating employees must continue to be carried out in a family atmosphere and according to Islamic values to form a genuinely Islamic-compliant institution. Islamic banks and financial institutions must indeed be role models in humanizing their workers. Every employee is part of the company's big family that needs attention when he is an active employee and even after retirement. He still feels like an essential part of the company.

Suppose the things above can be implemented in managing human resources/employees of banks and Islamic financial institutions. In that case, it is hoped that Islamic banks and financial institutions will be more advanced in the future and can play an essential role in the welfare of humanity. Public complaints state that Islamic banks and financial institutions are the same as conventional banks will gradually be eroded.

Build organizational commitment can be started from the selection process, which is the initial process to get prospective employees who can accept and support the culture and values of the organization. Furthermore, effective employee education and training programs will increase organizational commitment because the education and training process is a process of internalizing organizational values with individual values. This study will also explain the process of employee recruitment in Islamic banks and employee development in Islamic banking.

Recruitment is one of the crucial things in human resource management practices. A company must have an overview of the results of job analysis and job design by the needs and objectives of the company so that there needs to be filling positions with suitable and quality human resources for the job. Recruitment is essentially a process of determining and attracting qualified applicants to work in a company. It can be said that recruitment is a process to get several qualified human resources to occupy a position or job in a company. The motivation behind enrollment itself is to acknowledge however many candidates reasonably expected as per the capabilities of the organization's necessities from different sources, so it is feasible to select the most fabulous up-and-comers from the best. Recruitment activities are carried out when a company or organization requires workers and opens vacancies to get the desired candidate by the existing position or vacancy.

\section{CONCLUSION}

Human resources are the biggest asset for a company and function as capital (non-material/non-financial). This can be a substantial capital for a fundamental and comprehensive improvement for a bank. Human resources are the essential primary capital in every organization. The development of human resources is vital to meet the needs of human resources in Islamic banking institutions. Islamic work ethic and Islamic work culture are fundamental to instill in employees working in Islamic financial institutions. So it has the characteristics of siddiq, istiqamah, fathanah, amanah, and tablig. Someone who has and lives an Islamic work ethic will appear in his attitude and behavior that work is a form 
of worship, a call, and command from Allah that will glorify and humanize himself as part of the chosen people.

Universities have a role as a forum for learning and producing quality graduates in Islamic banking. For the development of Islamic financial, economic education, qualified and professional human resources are also needed. Islamic banking human resources must also be pious, have good morals (have the characteristics of being honest, fair, trustworthy, etc.), be diligent and work hard, have a thirst for knowledge, and be creative in developing scientific knowledge.

One of the essential keys to maintaining quality performance is developing and educating employees on an ongoing basis. Has a high commitment to improving the quality of human resources (human resources). With the occurrence of a Link and Match between universities and Islamic banking, with the arrangement of competent human resources in the field of Islamic, then Islamic banking does not need to recruit human resources from conventional banks and participate in quality research in qualitative research the field of Islamic banking. To improve the quality of employees, the bank provides education programs for new employees (banking staff program \& banking officer program) and promotional education in the form of officer development programs (ODP) that are specific according to position clumps. Competency development instills spiritual aspects, the quality of human resources based on Islamic principles, concerning individual aspects of knowledge, characteristics (motive, training, and values), and skills embedded in Islamic business values.

\section{REFERENCES}

Aulia, Ahmad. 2011. "Pengaruh Pelatihan Dan Pengembangan Sumber Daya Insan Terhadap Peningkatan Etos Kerja Pegawai Bank Syariah Bukopin Cabang Melawai.” Universitas Islam Negeri Syarif Hidayatullah Jakarta. https://repository.uinjkt.ac.id/dspace/bitstream/123456789/4531/1/100556AHMAD AULIA-FSH.PDF.

Bank Indonesia. 2012. "Laporan Perkembangan Perbankan Syariah." https://www.ojk.go.id/id/kanal/syariah/data-dan-statistik/statistikperbankan-syariah/Documents/DES15022013_1391738256.pdf.

Cahyani, Yutisa Tri. 2017. "Urgensi Sumber Daya Insani Dalam Institusi Perbankan Syariah.” Jihbiz: Jurnal Ekonomi, Keuangan Dan Perbankan Syariah 1 (1): 71-82. https://doi.org/10.33379/jihbiz.v1i1.675.

Fadlillah, Alnisa Min, and Krisno Septyan. 2020. "Model Pengembangan Kompetensi Sumber Daya Insani (SDI) Pada Bank Syariah." Jurnal Riset Manajemen Dan Bisnis (JRMB) Fakultas Ekonomi UNIAT 5 (3): 389-98. http://jrmb.ejournal-feuniat.net/index.php/JRMB/article/view/427.

Fauzan, Fauzan, and Irma Tyasari. 2012. "Pengaruh Religiusitas Dan Etika Kerja Islami Terhadap Motivasi Kerja.” Jurnal Ekonomi Modernisasi 8 (3): 20632. https://ejournal.unikama.ac.id/index.php/JEKO/article/view/787.

Firdiansyah, Fitra Azkiya, Achmad Rosidi, and Aldi Khusmufa Nur Iman. 2021. "Implementation Of Green Supply Chain Management In Halal Supply Chain Management - A Conceptual Model." ISLAMICONOMIC: Jurnal Ekonomi Islam 12 (1): 1-22. https://doi.org/10.32678/ijei.v12i1.257. 
Harahap, Sari Rezeki. 2016. "Pengaruh Strategi Pengembangan Sumber Daya Insani Terhadap Peningkatan Kinerja Dan Mutu Pelayanan Pada PT. Bank Muamalat Indonesia, Tbk Cabang Medan.” Analytica Islamica 5 (1): 14968. http://jurnal.uinsu.ac.id/index.php/analytica/article/view/484.

Hardana, Ali. 2015. "Manajemen Sumber Daya Insani." AL-MASHARIF: Jurnal Ilmu Ekonomi Dan Keislaman 3 (1): 115-26. http://jurnal.iainpadangsidimpuan.ac.id/index.php/Al-masharif/article/view/1057.

Hidayati, A. 2015. "Strategi Manajemen Sumber Daya Manusia Di Bank SYariah Mandiri Salatiga." Institut Agama Islam Negeri (IAIN) Salatiga. http:/erepository.perpus.iainsalatiga.ac.id/866/.

Istikhomah, Nurul, Ngadiman Ngadiman, and Sohidin Sohidin. 2014. "Analisis Kinerja Sumber Daya Insani BPRS Dana Amanah Ditinjau Dari Standar Kompetensi Kerja Nasional Indonesia." Jupe: Jurnal Pendidikan Ekonomi 2

109-23. https://jurnal.fkip.uns.ac.id/index.php/ekonomi/article/view/4181.

Jusmaliani, M. E. 2011. Pengelolaan Sumber Daya Insani. Surakarta: Bumi Aksara.

Latifah, Luluk, and Iskandar Ritonga. 2020. "Systematic Literature Review (SLR): Kompetensi Sumber Daya Insani Bagi Perkembangan Perbankan Syariah Di Indonesia." Al Maal: Journal of Islamic Economics and Banking 2 (1): 63. https://doi.org/10.31000/almaal.v2i1.2763.

Melis, Melis. 2019. "Pengelolaan Sumber Daya Insani Dalam Memasarkan Produk Dan Jasa Lembaga Keuangan Syariah." Islamic Banking : Jurnal Pemikiran Dan Pengembangan Perbankan Syariah 5 (1): 1-10. https://doi.org/10.36908/isbank.v5i1.65.

Moleong, Lexy J. 2011. Metodologi Penelitian Kualitatif. Bandung: PT. Remaja Berkarya.

Nafisah, Raudhatun. 2020. "Strategi Manajemen Sumber Daya Insani Pada Proses Konversi BPR Mustaqim Aceh (Analisis Realitas Dan Idealitas Kualifikasi Sumber Daya Insani Berdasarkan Nilai-Nilai Islam).” AT-TASYRI': Jurnal $\begin{array}{lllll}\text { Ilmiah Prodi } & \text { Muamalah } & 12 & \text { (1): } & 27 .\end{array}$ https://doi.org/10.47498/tasyri.v12i01.359.

Rahmawati, Nur. 2020. "Manajemen Sumber Daya Insani (Konsep Dasar Perencanaan Dan Analisis Jabatan Di Perbankan Syariah)." Justisia $\begin{array}{lllll}\text { Ekonomika } & 4 & \text { (1): } & 1-13 . & \text { http://journal.um- }\end{array}$ surabaya.ac.id/index.php/JE/article/view/5236.

Ramadani, Putri Dwi. 2019. "Manajemen Sumber Daya Insani Dalam Meningkatkan Kualitas Layanan (Studi Dikantor Kementerian Agama Provinsi Bengkulu).” Institut Agama Islam Negeri (IAIN) Bengkulu.

Rozalinda, Rozalinda. 2016. "Konsep Manajemen Sumber Daya Manusia: Implementasi Pada Industri Perbankan Syariah.” Al-Masraf: Jurnal Lembaga Keuangan Dan Perbankan 1 (1): 107-24. http://journal.febi.uinib.ac.id/index.php/almasraf/article/view/28.

Sari, Linda, Ridan Muhtadi, and Mansur Mansur. 2020. "Analisis Manajemen Sumber Daya Insani Pada Bank Pembiayaan Rakyat Syariah.” Ar-Ribhu: Jurnal Manajemen Dan Keuangan Syariah 1 (2): 27-35. https://ejournal.unzah.ac.id/index.php/arribhu/article/view/487.

Slocum, John W., Don Hellriegel, and Susan E. Jackson. 2008. Competency- 
Based Management. South-Western: Thomson.

Sumardjo, Mahendro, and Donni Juni Priansa. 2018. Manajemen Pengembangan Sumberdaya Manusia Konsep-Konsep Kunci. Bandung: Alfabeta.

Wikaningrum, Tri. 2011. "Praktek Dan Kebijakan Manajemen Sumber Daya Manusia Pada Perbankan Syariah.” Jurnal Siasat Bisnis 15 (1): 99-122. https://doi.org/10.20885/jsb.vol15.iss1.art8. 